\title{
Pengaruh Dosis Nitrogen terhadap Pembentukan Tunas dan Pertumbuhan Padi Ratun (Oryza sativa L.)
}

\section{Effect of Nitrogen Dose on Shoot Formation and Growth of Ratoon Rice (Oryza sativa<smiles>[AlH2]</smiles>

\author{
Tirto Wahyu Widodo ${ }^{\# 1}$, Damanhuri ${ }^{\# 2}$ \\ ${ }^{\#} J u r u s a n$ Produksi Pertanian Politeknik Negeri Jember Po Box 164 Jember; 68101 Indonesia \\ ${ }^{1}$ tirtowahyuwidodo@polije.ac.id
}

\begin{abstract}
Food security is the government's top priority in eradicating hunger. The government continues to make an innovation, so that food needs in Indonesia are fulfilled. One of them is increasing the rice harvest index to 5 times through the ratoon system. Currently, ratoon productivity is only $40-50 \%$ lower than its parent plant. Utilization of technology in the ratoon system is expected to increase plant productivity. This study aims to increase the productivity of the ratun by increasing the number of tillers which increase the growth of the ratoon. The experiment was arranged in completely randomized design (CRD). The factor tested were nitrogen dose $(50 \mathrm{~kg} \mathrm{ZA}$ / ha, $100 \mathrm{~kg} \mathrm{ZA} \mathrm{/} \mathrm{ha,} 150 \mathrm{~kg} \mathrm{ZA} \mathrm{/} \mathrm{ha,} 200 \mathrm{~kg} \mathrm{ZA} \mathrm{/} \mathrm{ha,} \mathrm{and} 250 \mathrm{~kg} \mathrm{ZA} \mathrm{/} \mathrm{ha)} \mathrm{repeated} 4$ times. The parent rice plant which used in the ratoon system was Inpari-32 variety. Collecting data were consisted number of tillers, length of panicles, number of grains per panicle, number of pithy grains, number of empty grains, and leaf chlorophyll

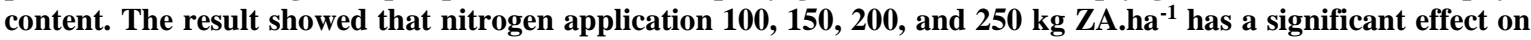

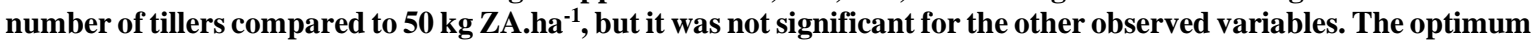
nitrogen dose to achieve the maximum number of tillers was $216.75 \mathrm{ZA}^{-h^{-1}}$. Increasing the level of nitrogen disposed to increase plant growth and yield component of ratoon rice, although it was not significant difference.
\end{abstract}

Keywords - nitrogen, shoot formation, ratoon

\section{Pendahuluan}

Perubahan iklim yang terjadi saat ini menuntut sektor pertanian untuk selalu melakukan adaptasi. Metode adaptasi yang sangat umum yakni memanfaatkan varietas toleran terhadap perubahan iklim, karena metode tersebut relatif paling mudah dilakukan [1]. Varietas padi toleran terhadap perubahan iklim dapat ditingkatkan masa produksinya melalui penerapan padi ratun. Produktivitas padi ratun berada pada kisaran 40-50\% lebih rendah dibandingkan tanaman induknya, namun budidaya padi ratun sangat sesuai untuk daerah yang kekurangan air akibat perubahan iklim [2].

Budidaya padi ratun memberikan peluang untuk meningkatkan intensitas tanam per satuan luas karena durasi tanam lebih singkat, kebutuhan tenaga kerja 50\% lebih sedikit, kebutuhan air $60 \%$ lebih sedikit, dan kebutuhan biaya lebih rendah walaupun rata-rata hasil 40-50\% lebih rendah dibandingkan tanaman induk [3]. Melalui budidaya padi ratun, indeks panen meningkat dari 3 menjadi 5 kali dalam setahun. Walaupun produktivitas padi ratun menurun setelah masa tumbuh kedua, melalui penerapan teknologi budidaya yang lebih baik, produktivitas padi ratun dapat ditingkatkan. Pemanfaatan teknologi budidaya padi ratun di Jawa Timur dapat meningkatkan produktivitas menjadi dua kali lipat tanpa melakukan penanaman ulang. Keuntungan lain penerapan budidaya padi ratun adalah lebih hemat biaya, tenaga kerja, sarana produksi, dan mengurangi waktu persiapan lahan. 
Teknologi yang dapat diterapkan pada budidaya padi ratun guna meningkatkan produktivitasnya adalah melalui rangsangan pembentukan anakan. Anakan padi baru yang tumbuh menjadi faktor utama produktivitas tanaman. Hal tersebut dikarenakan semakin banyak anakan yang terbentuk, maka jumlah anakan produktif juga akan meningkat, sehingga peluang peningkatan produktivitas semakin besar.

Pembentukan anakan pada padi ratun pertama hingga keempat tidak terlepas dari peran banyak faktor, salah satunya unsur hara. Unsur hara khususnya nitrogen menjadi faktor penting dalam merangsang pembentukan anakan. Nitrogen berperan dalam merangsang pertumbuhan tanaman melalui peningkatan jumlah anakan dan luas daun [4].

Aplikasi unsur nitrogen akan berpengaruh pada jumlah anakan yang selanjutnya juga akan meningkatkan jumlah malai pada padi ratun [5]. Selain berperan dalam merangsang pembentukan tunas baru, nitrogen juga dapat memicu pertumbuhan anakan ratun padi. Namun demikian, dosis nitrogen yang tepat dalam merangsang pembentukan tunas baru dan pertumbuhan anakan masih belum diketahui. Oleh karena itu, penelitian ini bertujuan untuk mendapatkan dosis nitrogen terbaik dalam merangsang pembentukan tunas baru dan pertumbuhan anakan ratun padi.

\section{Metode Penelitian}

\section{A. Waktu dan tempat}

Penelitian ini dilaksanakan pada bulan Mei sampai November 2020 bertempat di lahan Politeknik Negeri Jember.

\section{B. Bahan dan Alat}

Bahan yang digunakan dalam penelitian ini terdiri atas benih padi Inpari-32, ZA (sumber nitrogen), NPK, SP-36, KCl, dan pestisida. Alat yang digunakan dalam penelitian ini antara lain: bajak singkal, cangkul, garu, sprayer, alat tulis, dan label.

\section{Rancangan Percobaan}

Penelitian ini merupakan penelitian eksperimen lapangan yang dirancang dengan rancangan acak lengkap (RAL) non faktorial. Faktor yang diuji adalah dosis nitrogen yang terdiri atas 5 level, yakni $50 \mathrm{~kg} \mathrm{ZA} / \mathrm{ha}, 100 \mathrm{~kg} \mathrm{ZA} / \mathrm{ha}, 150 \mathrm{~kg} \mathrm{ZA} / \mathrm{ha}, 200 \mathrm{~kg}$ ZA/ha, dan $250 \mathrm{~kg} \mathrm{ZA/ha.} \mathrm{Setiap} \mathrm{perlakuan} \mathrm{diulang} 4$ kali.

\section{Tahapan Penelitian}

Tahapan penelitian terdiri atas penanaman tanaman induk (varietas Inpari-32), pemeliharaan tanaman induk, pemanenan, pemotongan tunggul padi, aplikasi perlakuan nitrogen, pemeliharaan ratun, pemanenan ratun, dan pengumpulan data.

\section{E. Data Pengamatan}

Data yang dikumpulkan dalam penelitian ini terdiri atas jumlah anakan, tinggi tanaman, jumlah malai, jumlah gabah per malai (gabah bernas dan gabah hampa), dan kandungan klorofil daun.

\section{F. Analisis Data}

Semua data yang diamati dilakukan analisis varian (anova) untuk mengetahui adanya pengaruh perlakuan. Setiap data pengamatan harus memenuhi syarat sebelum dilakukan analisis varian. Dua syarat yang harus dipenuhi adalah normalitas dan homogenitas ragam. Setiap data pengamatan yang menunjukkan berbeda nyata dan sangat nyata pada anova kemudian dilanjutkan dengan uji BNT untuk menguji beda rata-rata antar taraf perlakuan. Selain itu, untuk data jumlah anakan dilakukan analisis regresi polinomial kuadratik untuk menentukan dosis optimum nitrogen dalam mencapai anakan maksimum.

\section{Hasil Dan Pembahasan}

Varietas padi yang digunakan sebagai induk dalam percobaan ini adalah Inpari-32 yang memiliki umur panen 120 hari setelah tanam. Pada percobaan ini, umur panen padi ratun 81 hari setelah pemotongan tunggul, lebih cepat dibandingkan tanaman induknya. Hasil penelitian lain juga menunjukkan bahwa umur panen padi ratun varietas Ciherang antara 69-84 hari setelah pemotongan tunggul [6]. Hal tersebut dikarenakan setelah tunggul padi dipotong, anakan akan berbunga dan menghasilkan malai [7]. Panen berkorelasi dengan waktu pembungaan. Jika padi ratun lebih cepat berbunga, maka panen juga akan lebih cepat. Pada percobaan ini, padi ratun berbunga pada umur 31-42 hari setelah pemotongan tunggul. Penelitian lain juga menunjukkan bahwa padi ratun varietas Ciherang berbunga pada umur 30-44 hari setelah pemotongan tunggul [6].

Hasil penelitian ini menunjukkan bahwa dosis nitrogen berpengaruh nyata hanya terhadap jumlah anakan, namun berbeda tidak nyata pada variabel pengamatan lainnya. Rata-rata jumlah anakan sebagai respon dari aplikasi berbagai dosis nitrogen dapat dilihat pada Tabel 1 . 
Tirto Wahyu Widodo, Damanhuri. Pengaruh Dosis Nitrogen terhadap Pembentukan Tunas dan Pertumbuhan Padi Ratun (Oryza sativa L.)

TABEL 1. RATA-RATA JUMLAH ANAKAN PADA BEBERAPA DOSIS NITROGEN

\begin{tabular}{cc}
\hline Dosis N (kg ZA/ha) & Jumlah Anakan \\
\hline 50 & $13.48 \mathrm{~b}$ \\
100 & $19.17 \mathrm{a}$ \\
150 & $17.48 \mathrm{a}$ \\
200 & $21.44 \mathrm{a}$ \\
250 & $21.35 \mathrm{a}$ \\
\hline
\end{tabular}

Keterangan : angka-angka yang diikuti huruf yang sama menunjukkan berbeda tidak nyata pada taraf uji BNT 5\%

Aplikasi nitrogen bertujuan untuk menstimulasi pembentukan anakan padi ratun. Dosis nitrogen yang dapat membentuk anakan terbaik adalah 100, 150, 200, dan $250 \mathrm{~kg} \mathrm{ZA} / \mathrm{ha}$ karena menunjukkan perbedaan yang tidak nyata dibandingkan dosis $50 \mathrm{~kg}$ ZA/ha (Tabel 1). Walaupun perbedaan taraf nitrogen yang diaplikasikan cukup besar $(100,150,200$, dan $250 \mathrm{~kg}$ ZA/ha), namun jumlah anakannya berbeda tidak nyata. Hal tersebut diduga selain diserap oleh akar tanaman, nitrogen yang diaplikasikan ke tanah lebih banyak mengalami pencucian dan volatilisasi. Selain itu, penyerapan nitrogen masih kurang optimal karena pembentukan akar pada padi ratun lambat, sebab akar padi induk masih berfungsi. Oleh karena itu, efisiensi penggunaan nitrogen cukup rendah dikarenakan nitrogen banyak yang hilang.

Nitrogen merupakan nutrisi penting dalam pembentukan anakan karena menjadi komponen pembentukan hormon dan enzim yang memainkan peran penting dalam pertunasan padi ratun. Selain itu, nitrogen merupakan komponen yang terdapat pada semua bagian tanaman. Hasil penelitian lain menunjukkan bahwa aplikasi nitrogen dapat meningkatkan akumulasi nitrogen di daun dan batang padi ratun [8].

Dosis 100 - $250 \mathrm{~kg} \mathrm{ZA/ha} \mathrm{menunjukkan} \mathrm{hasil}$ terbaik pada jumlah anakan. Dari keempat taraf dosis tersebut dapat dicari dosis optimumnya dalam mencapai anakan maksimum. Penentuan dosis optimum nitrogen ( $\mathrm{kg} \mathrm{ZA/ha)} \mathrm{dalam} \mathrm{menghasilkan}$ anakan padi ratun maksimum dapat dilihat pada Gambar 1 .

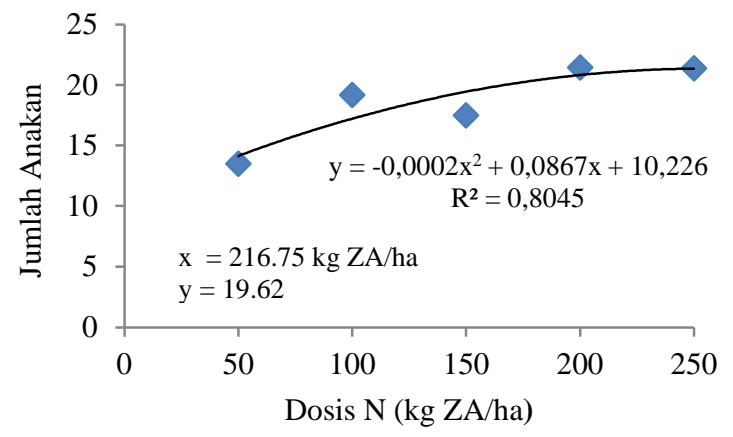

GAMBAR 1. ANALISIS REGRESI PENENTUAN DOSIS OPTIMUM N PADA PEMBENTUKAN JUMLAH ANAKAN PADI RATUN
Dosis optimum nitrogen dalam mencapai anakan padi ratun maksimum adalah $216.75 \mathrm{~kg} \mathrm{ZA} / \mathrm{ha}$. Penentuan dosis optimum tersebut bertujuan untuk menghemat penggunaan pupuk dan mendapatkan efisiensi serta efektivitas aplikasinya. Kelebihan aplikasi hara nitrogen justru mengakibatkan tanaman menjadi sukulen dan mudah terserang hama penyakit, sehingga produksinya akan menurun. Penambahan dosis pupuk yang berlebihan dapat mempengaruhi ketersediaannya bagi tanaman dan hasil tanaman akan menurun [9]. Hal tersebut dikarenakan produktivitas tanaman sesuai dengan konsep the law of diminishing return, dimana hasil tanaman akan optimal pada kondisi hara tertentu [10].

Nitrogen yang diaplikasikan ke dalam tanah akan diserap tanaman dalam bentuk ion ammonium dan nitrat. Kedua ion tersebut akan mengalami proses metabolisme di akar membentuk asam amino glutamat. Asam amino tersebut merupakan prekursor pembentukan klorofil di kloroplas daun. Rata-rata kandungan klorofil daun padi ratun dapat dilihat pada Gambar 2.

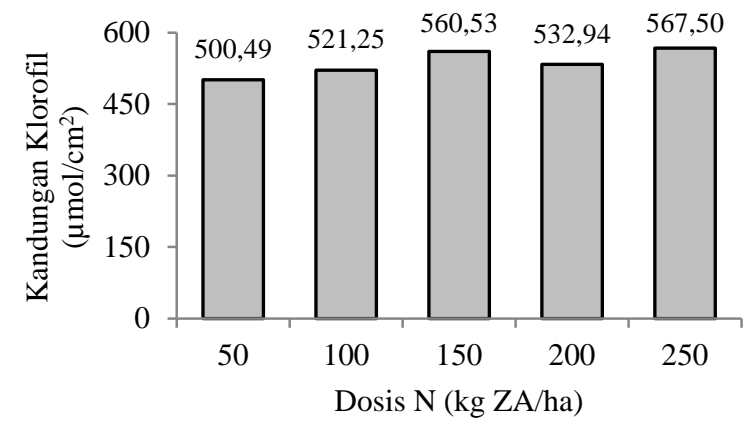

GAMBAR 2. RATA-RATA KANDUNGAN KLOROFIL DAUN PADI RATUN PADA BERBAGAI DOSIS NITROGEN

Kandungan klorofil daun pada berbagai taraf pemupukan nitrogen berbeda tidak nyata. Terdapat kecenderungan peningkatan kandungan klorofil sebagai respon terhadap peningkatan dosis nitrogen, walaupun tidak signifikan. Peningkatan kandungan klorofil merupakan salah satu respon terhadap nitrogen yang diserap tanaman. Kadar nitrogen yang tinggi di tanaman dapat meningkatkan kandungan klorofil dan turgiditas sel daun [11].

Salah salah penyusun klorofil daun adalah nitrogen, dimana nitrogen yang diserap tanaman selain berasal dari pupuk ZA juga berasal dari tanah. Efisiensi penggunaan nitrogen yang rendah dan banyaknya nitrogen yang hilang menjadi penyebab kandungan klorofil daun tidak signifikan pada semua taraf nitrogen.

Proses fotosintesis tidak terlepas dari peran klorofil. Hasil fotosintesis berupa fotosintat akan ditranslokasikan ke semua bagian tanaman, baik digunakan sebagai energi untuk pertumbuhan selama fase vegetatif maupun disimpan selama fase generatif. Energy yang berasal dari fotosintat salah satunya 
digunakan oleh sel untuk pemanjangan sel. Kondisi tersebut dapat dilihat secara visual berdasarkan tinggi tanaman dan panjang malai. Rata-rata tinggi tanaman dan panjang malai dapat dilihat pada Tabel 2 .

TABEL 2. RATA-RATA TINGGI TANAMAN DAN PANJANG MALAI
\begin{tabular}{ccc} 
PADI RATUN PADA BEBERAPA DOSIS NITROGEN & \\
\hline $\begin{array}{c}\text { Dosis N } \\
(\mathrm{kg} \mathrm{ZA} / \mathrm{ha})\end{array}$ & $\begin{array}{c}\text { Tinggi Tanaman } \\
(\mathrm{cm})\end{array}$ & $\begin{array}{c}\text { Panjang } \\
\text { Malai }(\mathrm{cm})\end{array}$ \\
\hline 50 & 54.50 & 17.31 \\
100 & 60.56 & 18.48 \\
150 & 58.06 & 17.93 \\
200 & 61.17 & 19.15 \\
250 & 57.89 & 18.50 \\
\hline
\end{tabular}

Tinggi tanaman dan panjang malai berbeda tidak nyata pada semua taraf pemupukan nitrogen. Tinggi tanaman dan panjang malai cenderung meningkat seiring peningkatan dosis nitrogen, walaupun tidak signifikan.

Pada fase generatif, sebagian besar fotosintat akan ditranslokasikan ke bagian penyimpanan yakni gabah. Rata-rata jumlah gabah, gabah bernas, dan gabah hampa per malai dapat dilihat pada Tabel 3.

Tabel 3. RATA-RATA KOMPONEN HASIL PADI RATUN PADA BEBERAPA DOSIS NITROGEN

\begin{tabular}{cccc}
\hline $\begin{array}{c}\text { Dosis N } \\
(\mathrm{kg} \text { ZA/ha) }\end{array}$ & $\begin{array}{c}\text { Jumlah } \\
\text { Gabah } \\
\text { Per } \\
\text { Malai }\end{array}$ & $\begin{array}{c}\text { Jumlah Gabah } \\
\text { Bernas Per } \\
\text { Malai }\end{array}$ & $\begin{array}{c}\text { Jumlah } \\
\text { Gabah } \\
\text { Hampa Per } \\
\text { Malai }\end{array}$ \\
\hline 50 & 80.31 & 69.35 & 10.96 \\
100 & 82.69 & 75.80 & 6.89 \\
150 & 86.11 & 75.83 & 10.28 \\
200 & 89.96 & 80.46 & 9.50 \\
250 & 87.29 & 79.66 & 7.63 \\
\hline
\end{tabular}

Rata-rata komponen hasil padi ratun tersebut menunjukkan perbedaan yang tidak nyata. Jumlah gabah dan gabah bernas cenderung meningkat seiring kenaikan taraf nitrogen, sedangkan jumlah gabah hampa cenderung menurun walaupun tidak signifikan. Nitrogen menjadi bagian dari hormon auksin yang berperan dalam pembelahan dan pemanjangan sel. Peningkatan nitrogen di bagian tanaman sampai batas tertentu dapat meningkatkan biosintesis hormon auksin, sehingga akan terjadi peningkatan pembelahan dan pemanjangan sel. Kondisi tersebut akan memberikan peluang lebih besar untuk hasil fotosintesis disimpan di bagian penyimpanan ( $\operatorname{sink})$ yakni biji.

\section{IV.KESIMPULAN}

Aplikasi nitrogen $(100,150,200$, dan $250 \mathrm{~kg}$ ZA/ha) menghasilkan jumlah anakan yang signifikan dibandingkan $50 \mathrm{~kg}$ ZA/ha, namun tidak signifikan pada variabel pengamatan lainnya. Dosis optimum nitrogen untuk mencapai jumlah anakan maksimum adalah $216.75 \mathrm{~kg}$ ZA/ha. Peningkatan taraf pemupukan nitrogen cenderung meningkatkan pertumbuhan tanaman (tinggi tanaman dan panjang malai) serta komponen hasil (jumlah gabah dan gabah bernas per malai).

\section{UCAPAN TERIMA KASIH}

Penulis menghargai dukungan pendanaan dari PNBP Politeknik Negeri Jember Tahun 2020, sehingga penelitian dan penulisan artikel ini terlaksana dengan baik.

\section{DAfTAR PUSTAKa}

[1] Sugihardjo. Model Adaptasi Ekologi Petani Sebagai Strategi Pengelolaan Usahatani Akibat Perubahan Iklim (Kasus Di Daerah Aliran Sungai Cemoro, Jawa Tengah, Indonesia). Disertasi. Pascasarjana Universitas Sebelas Maret, 2016.

[2] Direktorat Jendral Prasarana dan Sarana Pertanian. Optimalisasi Lahan Melalui Teknologi Salibu, satu kali tanam 3 kali panen 1 tahun. Dirjen Prasarana dan Sarana. Kementerian Pertanian, 2013.

[3] R. B. Negalur, G. S. Yadahalli, B. M. Chittapur, G. S. Guruprasad \& G. Narappa. Ratoon Rice: A Climate and Resource Smart Technology. International Journal of Current Microbiology and Applied Sciences, vol. 6, pp. 1638-1653, 2017.

[4] E. Kaya. Pengaruh Kompos Jerami dan Pupuk NPK Terhadap N-Tersedia Tanah, Serapan-N, Pertumbuhan, dan Hasil Padi Sawah (Oryza sativa L). Jurnal Agrologia, vol. 2, pp. 43-50, 2013.

[5] Alfandi. Pengaruh Tinggi Pemangkasan (Ratun) dan Pupuk N terhadap Produksi Padi (Oryza sativa L.) Kultivar Ciherang. Jurnal Agrijati, vol. 2, pp. 1-7, 2006.

[6] V. C. Nuzul, D. Indradewa \& D. Kastono. Pengaruh Waktu dan Tinggi Pemotongan Tunggul terhadap Komponen Hasil da Hasil Padi (Oryza sativa L.) Ratun. Vegetalika,vol. 7, pp. 54-65, 2018.

[7] Susilawati, B.S. Purwoko, H. Aswidinnoor, \& E Santosa. Tingkat Produksi Ratun Berdasarkan Tinggi Pemotongan Batang Padi Sawah Saat Panen. J. Agron. Indonesia, vol. 40, pp. 1-7, 2012.

[8] M. S. Islam, M. Hasannuzzaman \& M. Rukonuzzaman. Ratoon Rice Response to Different Fertilizer Doses in Irrigated Condition. J. Agriculture Conspectus Scientificus, vol. 73, pp. 197-202, 2008.

[9] D. Dahlan, Y. Musa, \& M. I. Ardah. Pertumbuhan dan Produksi Dua Varietas Padi Sawah pada Berbagai Perlakuan Rekomendasi Pemupukan. J. Agrivigor, vol. 11, pp. 271, 2012.

[10] A. S. Wahid. Peningkatan Efisiensi Pupuk Nitrogen pada Padi Sawah dengan Metode Bagan Warna Daun. J. Litbang Pertanian, vol. 22, pp. 156, 2003.

[11] Y. J. Lee, C. M. Yang, K. W. Chang, \& Y. Shen. Effects of nitrogen status on leaf anatomy, chlorophyll content and canopy reflectance of paddy rice. Botanical Studies, vol. 52, pp. 295-303, 2011. 